Krzysztof RAJTARSKI, BA

Faculty of Economics and Finance, University of Bialystok

e-mail: krzy3h@wp.pl

ORCID: 0000-0002-1458-1008

DOI: $10.15290 /$ oes.2020.02.100.12

\title{
POLITICAL PROBLEMS CONNECTED WITH THE EFFICIENT REALIZATION OF THE NATURE CONSERVATION POLICY IN THE GLOBAL ECONOMY ${ }^{1}$
}

\begin{abstract}
Summary
Purpose - The aim of the paper is to indicate the reasons for too insignificant determination of some countries with regards to the issue of environmental protection.

Research method - Acritical analysis of the literature together with deductive reasoning have been used. Among the quantitative methods, the author employed the use of the simple tools of descriptive statistics.

Results - One of the reasons for too insignificant determination of some countries relating to issues in environmental protection is competition for the hegemony position they are involved in. The conservation of nature demands expenditure, which could be used to achieve higher economic growth. In the conditions of countries' competition for the hegemony title, higher economic growth enables beneficial solving of the conflict.

Originality/value - The author attempts to explain the reason for too low determinations of some countries in environmental protection, which is a current topic. Understanding the reason may contribute to helping to solve the problem of environmental protection on a global scale.
\end{abstract}

Keywords: sustainable development, prisoner dilemma, the tragedy of the commons, world hegemony

JEL Classification: C71, D74, F51, Q53, Q58

\section{Introduction}

The problem of natural environmental protection has been acknowledged for a long time. Each civilization that achieved a sufficiently high level of economic growth experienced the unfavourable effects of the pollution of the natural environment [Dobrzańska et al., 2012, p. 49]. It resulted chiefly from the adoption of the extensive model of growth ${ }^{2}$.

${ }^{1}$ Article received on 20 January 2020, accepted on 25 March 2020.

2 The extensive model of economic growth means the increase in the inputs of growth factors. It is frequently connected with the degradation of the state of the natural environment, which can be exemplified by today's rainforests in Brazil and the Amazon being cut down for housing purposes. 
The present environmental challenges are much more serious and complex than in the past. They were noticed in the second half of the $20^{\text {th }}$ century and subsequently became more visible after the publication of $U$. Thant's report in 1969. At the time, public attention was drawn to the fact that environmental problems were beginning to occur on a global scale and included, among others [Dobrzańska et al., 2012, pp. 96, 108, 138, 254]: the excessive emission of carbon dioxide and other chemical compounds into the atmosphere, the destruction of the ozonosphere and the desertification of inhabited areas, etc.

Since that period regular discussions have taken place around the protection of nature, while countries have pledged to undertake certain actions in this sphere. The problem of natural environmental protection is still valid, the evidence of which is the present lively dialogue on the topic amongst politicians, journalists and scientists. They bring global attention to the insufficient involvement of countries and international institutions in natural environmental protection, which can be exemplified by the speech delivered by 16-year old Greta Thunberg at a session of the UN assembly [www 1].

The aim of this paper is to point at the reason of the low determination of some countries in relation to environmental protection. It appears that the indication and analysis of these reasons may help the critics of present governments to understand the deadlock in the implementation of the idea of eco-development. Moreover, the author aims to verify the following hypothesis: "A country will not conduct efficient strategies of natural environmental protection in the conditions of the quest for hegemony".

\section{The idea of eco-development}

The concept of eco-development was formed as a reaction to the proceeding degradation of the natural environment. It was observed that high economic growth, which was recorded in the $19^{\text {th }}$ and $20^{\text {th }}$ century, took place at the cost of the natural environment. This observation enabled the formulation of at least two conclusions:

- the level of economic growth is not the only factor that has impacted people's standards of living. Another factor may be the state of the natural environment, the deterioration of which (ceteris paribus) will result in lowered standards of living [Kośmicki, 2012, p. 47];

- the achievement of stable economic growth is impossible in the situation of the degradation of the state of nature. The natural environment is one of the production factors and its degradation will hamper the supply of goods (by nature) which are later processed by man [Janik et al., 2009, p. 14].

Taking into consideration the aforementioned conclusions it was stated that economic growth ought to comprise not only the production of goods and services, but also environmental issues. During the shaping of the idea of eco-development (especially after the World Summit in Johannesburg) public attention was drawn 
towards social issues (income inequalities, the problem of poverty etc.) as the equal objective of realising sustainable economic activity. It was established that ecodevelopment does not possess sufficient capacity. As a result, it was overwritten by the idea of sustainable development. Sustainable development may be treated as the balance of economic objectives (economic growth of quantity character), ecological objectives (natural environmental protection) and social objectives (combating poverty and fair income distribution) [Rogall, 2010, p. 49]. The impact of social objectives on environmental protection is not analysed in this paper although this component of stable development emerges here in order to demonstrate the actual understanding of this concept. Such an understanding of stable development is presented in chart 1 .

CHART 1

\section{Sustainable development as a common area of three spheres of man's life}

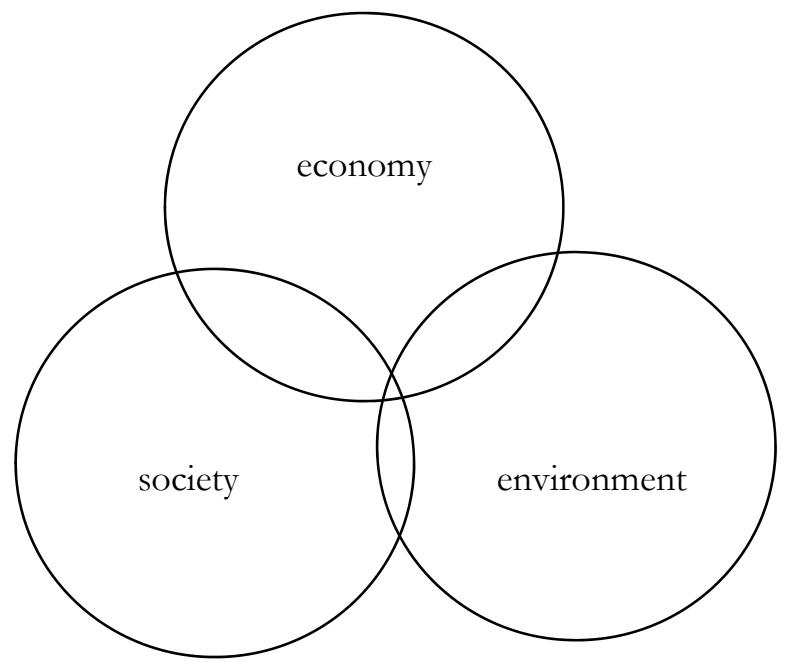

Source: own elaboration based on: [Florczak, 2011, p. 288].

The environmental aspect of stable development is primarily focused on two issues: firstly, the hazard connected with the scarcity of resources and secondly, the degradation of the natural environment.

It is assumed that the debate on the scarcity of resources was initiated by Malthus [1925, pp. 61-62] in his book "An Essay on the Principle of Population". In his opinion the rate at which the number of people increases, is faster than the rate at which the means of subsistence increase. This implies the permanent state of poverty of population owing to the lack of possibility to obtain more resources. The opposite side of the debate shows that Malthus did not take into consideration several factors that improve the work efficiency, especially as regards the increase of knowledge. The increase of knowledge resource enables the acquisition of new 
resources and more effective usage of the already obtained ones. It enables postponing the "Malthusian trap" [Bartkowiak, 2013, pp. 94-95], which is presented in chart 2.

CHART 2

The role of technical progress in improving the productive capacity of the economy

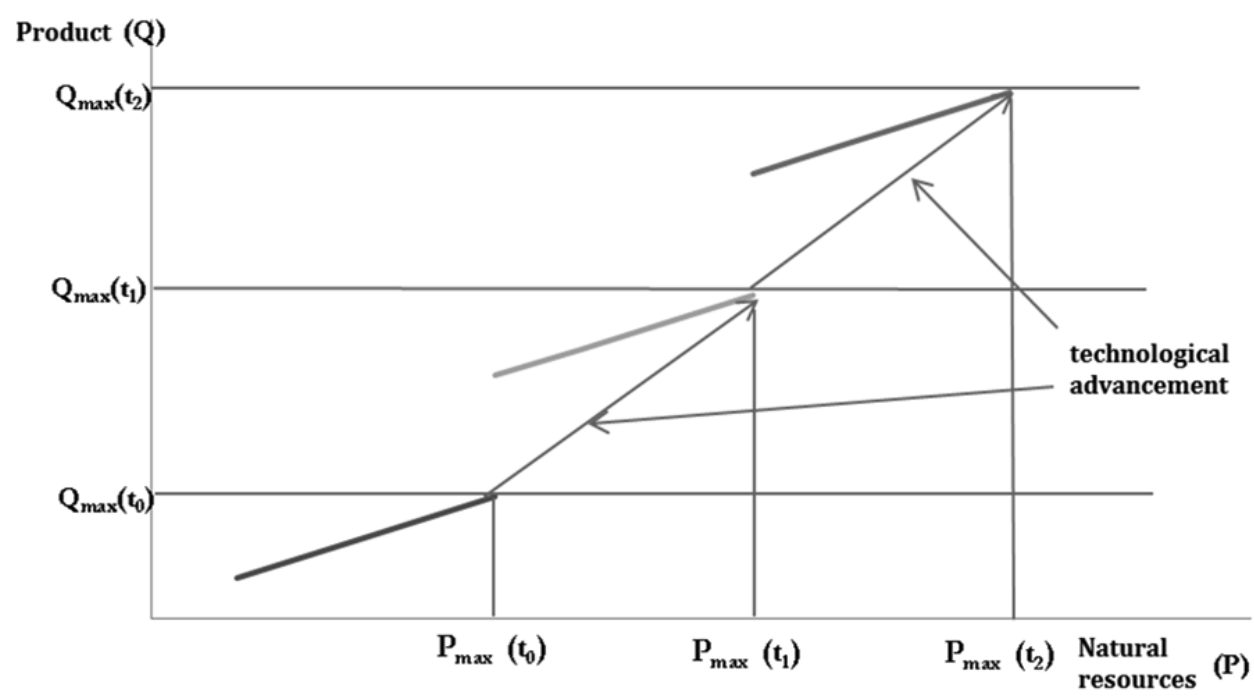

Source: [Bartkowiak, 2013, p. 95].

It appears that a more hazardous problem is the proceeding degradation of the natural environment. Humankind must struggle with such consequences [Dobrzańska et al., 2012, pp. 96, 108, 138, 254] as: the desertification of polluted areas, the irreversible disappearance of many animal and plant species, tree felling, global warming and climate change, etc. It apparent that the unrestricted market system does not provide incentives for natural environmental protection. The opposite view was expressed by Simon Kuznets, who argued that in the situation of free market, people will take care of the environment. In accordance with the concept of the environmental Kuznets curve, the degree of the pollution of the natural environment is increasing simultaneously with the increasing economic growth only to a certain level. Above a certain level of wealth people begin to appreciate a cleaner environment, which motivates them to protect it [Rogall, 2010, pp. 278, 279]. However, it is estimated that in order to reduce the scale of pollutions in a voluntary way by means of a market system, a society must achieve a very high level of GDP per capita. Until then, the state of the environment must be degraded to such degree that its restitution will prove to be impossible or will require incurring huge expenditure [Żylicz, 2014, p. 226]. Therefore, it appears to be justified that natural environmental protection is one of the responsibilities of a country. 


\section{The national income level versus the state of the natural environment}

A lower rate of economic growth is the alternative cost of the improvement of the state of the natural environment. It is possible to isolate three reasons of such dependency:

1. The abandonment of economic activity in some economic sectors. It is the most radical way of reducing environmental pollution as it considerably reduces a global product.

2. The change of production methods into a more environment-friendly one. There are frequently many production methods among which companies attempt to choose the optimal one [Mankiw, Taylor, 2017, pp. 251-257]. More capital absorbing production methods are usually more productive than labour-intensive and at the same time relate to greater pollution of the natural environment. Therefore, in order to protect nature, it is necessary to change the method into a more labour intensive one (reversed substitution technological progress).

3. The increase in expenditure on $\mathrm{R} \& \mathrm{D}$ as regards to environmental protection. New technologies frequently enable economic activity to exert less pressure on nature and at the same time maintain the same productivity. However, this method of environmental protection is connected to alternative costs of increased expenditure. The resources allocated for R\&D could be used to produce more goods and services. In this case, the improvement of the state of the environment entails the lower rate of economic growth than the potential one Janik et al., 2009, p. 111].

In view of the above, the state of the natural environment is the function of national income. This dependence is presented in the following equation:

where:

$$
\mathrm{p}=\mathrm{f}(\mathrm{Y})
$$

$\mathrm{p}$ - the state of the natural environment

$\mathrm{Y}$ - the level of national income

The previously mentioned function is characterized by the following dependencies:

$$
\mathrm{f}^{\prime}(\mathrm{Y})<0 ; \mathrm{f}^{\prime \prime}(\mathrm{Y})<0
$$

The relationship between the state of the natural environment and the level of the national income is presented in chart 3 . 
CHART 3

\section{The state of the natural environment versus the level of the national income}

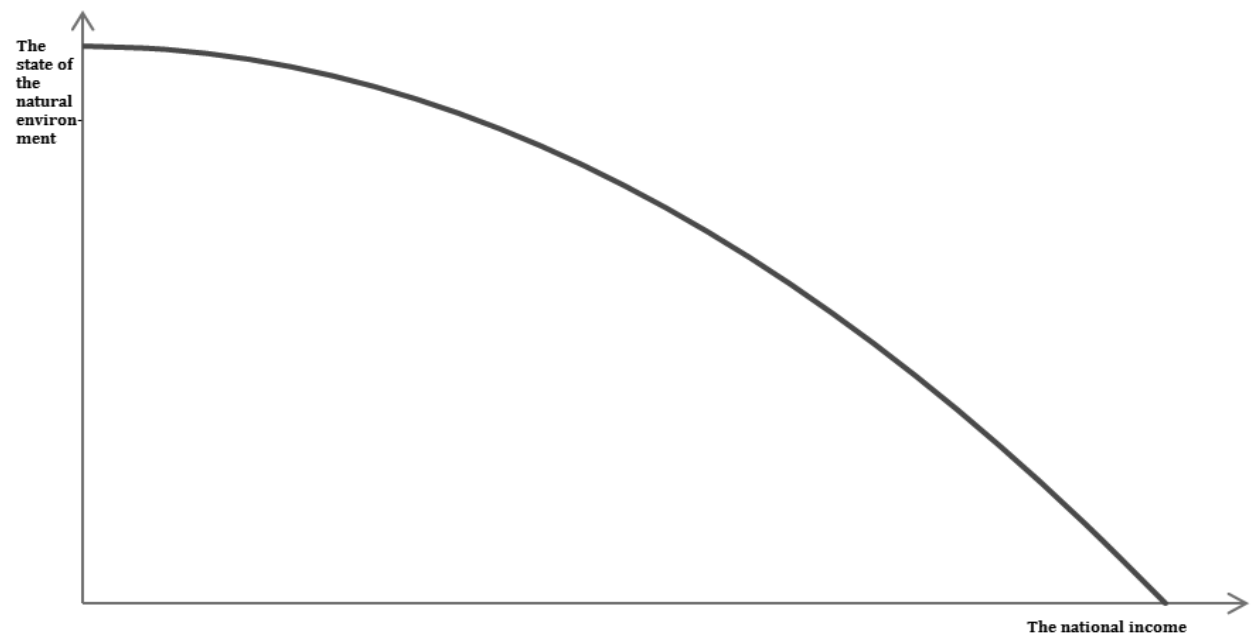

Source: [Politykea ..., 2002, p. 382].

It needs to be emphasised that the relationship presented above relates only to a certain time period which may be named "the short period". The criterion that distinguishes between the short period and the long one is the emergence of technological advancement which enables the change of economic structure. Its result is the higher quality of the environment and the higher level of the national income. A good example that illustrates the impact of technological advancement is the change of structure of highly developed economies in the $20^{\text {th }}$ century from those based on heavy industry into the ones based on the service sector.

Therefore, one may conclude that irrespective of the character of the nature protection policy that countries decide to pursue, in the short term it must lead to the reduction of the national income (in absolute terms or the potential national income). It entails several problems and any environmental protection policy must almost inevitably run into difficulties. However, the author decided to focus on the aspect connected with the international policy of particular countries.

\section{The competition of countries for hegemony versus the environmental protection policy}

History shows that states strive for the domination over their neighbours in order to win the title of hegemony. In the past, the main aspiration was to make other countries subordinate and to dominate in military terms. Presently mostly non-conventional methods are used - domination is in the spheres of culture, 
economy, politics and technologies [Eberhardt, 2012, pp. 319, 323], but the possession ofsubstantial military forces remains crucial. Each path leading to domination requires the possession of a strong economy that develops in a dynamic way [Kleinowski, 2010, pp. 15, 16]. Without a strong economy, it is impossible to conduct advanced technical research, threaten the economic safety of other countries and, finally, it is impossible to achieve cultural domination. Therefore, the maximising of the rate of economic growth is frequently the priority that lays claim to the title of hegemony among countries.

Conducting efficient policy related to environmental protection in the conditions of the struggle for domination is particularly difficult or even impossible. It results from the contradiction of two objectives (the economic and ecological ones). In the conditions of the struggle for domination, one can frequently observe that economic objectives prove to be more important than the ecological objectives. It is only after the selection of a clear hegemon and shaping new international order that it becomes possible torealise ecological objectives.

There can be noticed a problem which in literature is referred to as the tragedy of the commons. It is connected to the existence of a common good (the natural environment) which is characterised by the impossibility of excluding someone from consumption and by the existence of competition as regards consumption. Each country may take advantage of the natural environment and pollute it, among others, by the excessive emission of carbon dioxide. Each of them gains thanks to the additional emission of carbon dioxide (and at the same time increases its national income), but the environmental costs of the emission are also distributed among other entities that make use of the environment. As a result, no one has incentives to protect the environment and ultimately everyone will sense the cost of the ruined planet [Prandecki, 2016, s. 59, 60].

In the conditions of the struggle for domination, environmental protection appears to be even more difficult. The analysis of profits and losses of the hegemon or the pretender is wellillustrated using the case known as the prisoner's dilemma [Binmore, 2017, pp. 27-29]. Four scenarios are possible (table 1):

1. Both players realise an environmental protection policy. The result of this scenario is a considerably less polluted environment and the same proportion of national incomes of the players (having impact on the domination possibility described above) as well as before starting the activity.

2. Hegemon decides to realise an environmental protection policy, while the pretender does not. Then the natural environment is slightly less polluted, while the proportion of national incomes of the players, including the possibility of domination, changes in favour of the pretender.

3. Pretender decides to realise environmental protection policy while the hegemon remains passive in this aspect. In such a situation the state of the natural environment improves slightly, while the proportion of national incomes changes in favour of the hegemon. 
4. Both players decide not to realise policy related to environmental protection. Its state remains unchanged, however the proportion of national incomes does not change as well.

Table 1 shows that the dominating strategy of the hegemon will not be the realisation of an environmental protection policy. If a pretender decided to realise such policy, the hegemon would gain economic profits from this decision by becoming considerably stronger than the pretender. However, if the hegemon attempted to protect the environment, it would be neither stronger nor weaker. As regards the pretender's decision to realise an environmental protection policy, the best decision made by the hegemon is not to realise the environmental protection policy.

TABLE 1

The struggle over domination between the hegemon and the pretender

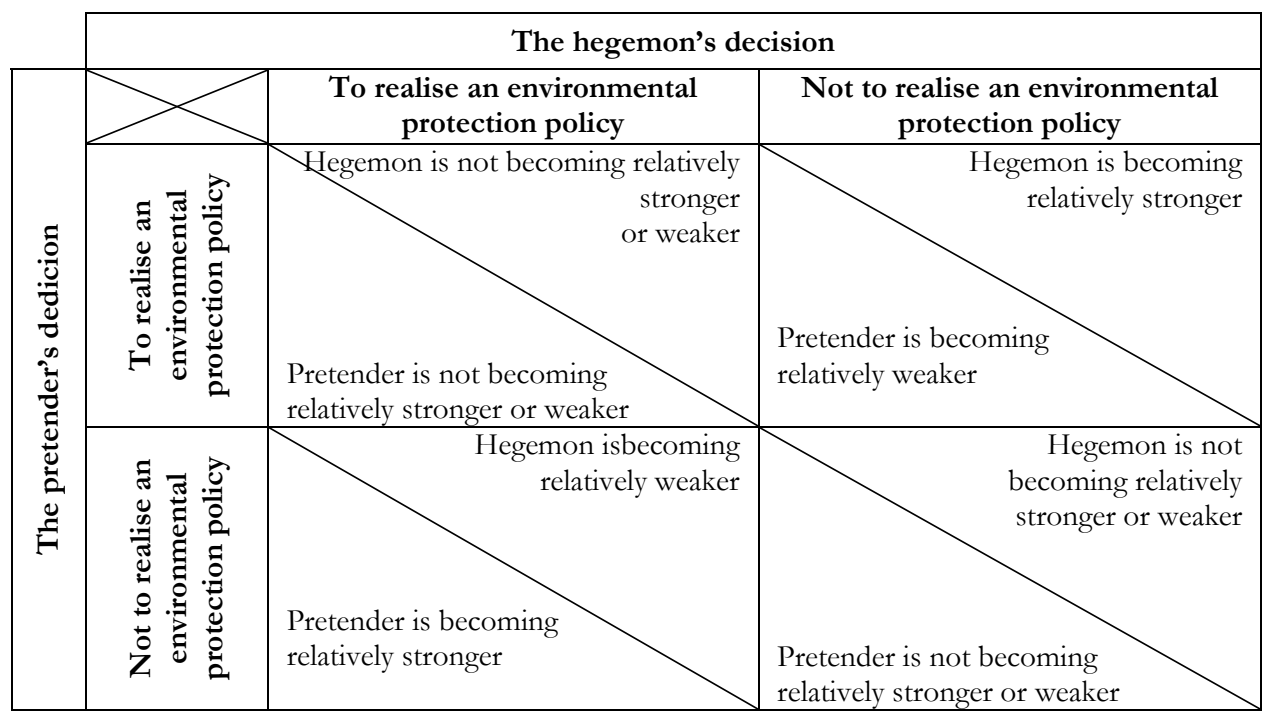

Source: own elaboration.

It is similar in the situation where the pretender does not comply with the environmental protection policy. Here the hegemon's decision to realise the environmental protection policy will result in it becoming weaker than the pretender. Meanwhile the hegemon's decision to not realise the environmental protection policy will lead to the situation where none of them gains advantage. In this situation the hegemon will gain most if it does not realise the environmental protection policy.

Therefore, the hegemon's decision not to realise the environmental protection policy is the best solution (for the hegemon) irrespective of the decision made by the pretender. Therefore, it is the hegemon's dominating strategy [Heifetz, 2012, pp. $23,24]$. A similar analysis of gains and losses may be made as regards the pretender, but it will be identical as it is for the hegemon. With regards to the pretender, the 
decision to not realise the environmental protection policy is also most profitable and as the result, it is its dominating strategy. Since both dominating strategies are identical, the only Nash equilibrium [Heifetz, 2012, pp. 66, 67] is the situation where both players do not realise the environmental protection policy. In this situation none of the players loses advantage over the other one as regards the realisation of the environmental protection, but both must have losses due to the polluted environment. The tragedy of the commons is related to the fact that both could gain from clean environment in the situation of equal chances related to this policy, but it is impossible to achieve in these conditions.

It appears that the situation described above takes place in the contemporary world. Many scientists analysing geopolitics emphasise that after the Cold War the United States maintained the status of the global hegemon. After only 20 years a new pretender emerged in this domain. Nowadays almost no one appears to have doubts that China is a new pretender that can replace the United States in the role of the global hegemon and question the order that was established by the USA [Bartosiak, 2016, pp. 89, 330]. According to the author, the quest for global domination of these two superpowers does not favour the realisation of proper environmental protection policy by none of the sides.

\section{The analysis of environmental protection policy of selected countries}

One of the major environmental problems worldwide is the excessive emission of carbon dioxide. It contributes to the warming of the global climate, which relates to numerous consequences in the natural environment of mostly negative character. The reduction of such consequences makes this occur only by means of reducing the emission of greenhouse gases. Table 2 presents the annual emission of carbon dioxide (in mln tons) of particular countries in selected time cross-section, their participation as the percentage of the global emission and the emission dynamics.

The data from table 2 shows that the United States and China in 2017 were responsible for more than $40 \%$ of the total emission of carbon dioxide. Therefore, it appears to be clear that the realisation of efficient environmental protection policy in a global dimension without the participation of these two countries is impossible or extremely difficult. It results from the huge costs of realising such policy by all other countries that would need to reduce the emissions even more than in the situation where the USA and China realise responsible environmental protection policy. While highly developed countries would be inclined to such solutions (relatively insignificant decrease of GDP in comparison with the increase of the environment quality), developing countries would rather be uninterested in it (relatively large decrease of GDP in comparison with the increase of the environment quality). 
TABLE 2

\section{The emission of $\mathrm{CO} 2$ in selected countries worldwide in the years 2000-2017}

\begin{tabular}{|c|c|c|c|c|c|}
\hline \multirow[t]{2}{*}{ Countries } & \multicolumn{3}{|c|}{$\begin{array}{l}\text { The emission of carbon dioxide ( } \mathrm{mln} \\
\text { tons) }\end{array}$} & \multirow{2}{*}{ 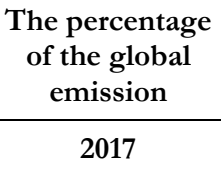 } & \multirow{2}{*}{$\begin{array}{c}\text { The percentage } \\
\text { changes of the } \\
\text { emissions }\end{array}$} \\
\hline & 2000 & 2007 & 2017 & & \\
\hline Brazil & 292.4 & 329.7 & 427.6 & $1.3 \%$ & $46.3 \%$ \\
\hline China & 3099.7 & 6471.2 & 9257.9 & $28.2 \%$ & $198.7 \%$ \\
\hline India & 884.7 & 1257 & 2161.57 & $6.6 \%$ & $144.3 \%$ \\
\hline Pakistan & 94.4 & 136.4 & 183.5 & $0.56 \%$ & $94.3 \%$ \\
\hline Poland & 289.6 & 306.3 & 305.8 & $0.9 \%$ & $5.6 \%$ \\
\hline RSA & 280.5 & 391.5 & 421.7 & $1.3 \%$ & $50.3 \%$ \\
\hline Russia & 1474.4 & 1533.7 & 1536.9 & $4.7 \%$ & $4.2 \%$ \\
\hline $\mathrm{EU}$ & 3786.1 & 3872.8 & 3209.3 & $9.8 \%$ & $-15.2 \%$ \\
\hline USA & 5729.9 & 5686.7 & 4761.3 & $14.5 \%$ & $-16.9 \%$ \\
\hline Worldwide & 23223.4 & 28979.7 & 32839.9 & $100 \%$ & $39.2 \%$ \\
\hline
\end{tabular}

Source: own elaboration on the based: [www 8].

The hypothesis regarding the lack of efficient environmental protection policy in the situation of the rivalry for global domination appears to be confirmed by China. The emission of carbon dioxide in China was almost three times higher in 2014 than in 2000. While environmental protection policy is only one of numerous variables that have an impact on the emission levels, one must not forget that the economy of China is still one of the most dynamically developing global economies and it is still in the industrial phase. It has undoubtedly a major impact on the level and dynamics of the emission of carbon dioxide.

It could appear that China's adoption of the Paris agreement refutes the aforementioned hypothesis. However, the author of this paper does not agree with this opinion. Indeed, China signed the Paris agreement, however the limits imposed on particular countries are not identical. For example, China has undertaken to reduce the emission of carbon dioxide as late as after 2030 [www 2] arguing that it is still a developing country which does not have the obligation to take care of the global climate to the same degree as developed countries. Therefore, it appears that the environmental protection policy realised by China is only apparent. However, it enables China placing itself in the role of global hegemon that must positively respond to the necessary combat with climate change in order to be recognised by the international community.

Contrary to China, the decreasing emissions level of the United States appears not to confirm the hypothesis since it decreased by nearly $17 \%$ in the years 2000 2017. However, as it was stated above, an environmental protection policy is one of the elements that have an influence on the level of the emission of carbon dioxide. 
According to the author, the US environmental protection policy is becoming considerably less restrictive. This is confirmed by the following facts - there were 85 environmental regulations at the federal level that were abolished or gradually withdrawn (e.g.: the provisions that were supposed to guarantee clean drinkable water were abolished; as was the provision regarding making reports on the emission of methane in relation to companies) [www 3]. In 2018, the level of emissions of carbon dioxide increased for the first time over the last couple of years, which may be partly caused by the suspension of these regulations.

This opinion was confirmed in the declaration of President Donald Trump in June 2017 on the withdrawal of the United States from the Paris Agreement. The President declared that "[the USA - author] would end the implementation of the provisions of the non-binding Paris Agreement and draconian financial and economic burdens imposed on our country" [www 4]. Donald Trump argues that it is "not beneficial for American employees and tax payers" [www 5] and emphasised that he is unwilling/does not want to "punish Americans and make the poisoners rich" [www 6]. At the same time Donald Trump stresses that the United States is "the global leader in reductions in the emission of $\mathrm{CO}_{2}$ " [www 7]. These words clearly indicate that the United States is not going to realise efficient environmental protection policy at the cost of its economy, especially in the situation where the beneficiary of such state of affairs would be China, the more so because the United States is the leader in reducing the emission of carbon dioxide, which is confirmed by data. According to the author, these words and action confirm the hypothesis concerning the lack of possibility to realise efficient environmental protection policy in the situation of the competition for global domination. They indicate that the United States (hegemon) fears the increasing economic power of China (pretender), which makes it forced to concentrate on maintaining the position of hegemon.

What is then the reason of almost a $17 \%$ reduction in the emission of carbon dioxide in the years 2000-2017? There are numerous reasons and this issue will not be solved by the author in this paper. However, it should be emphasised that in the first decade of the $21^{\text {st }}$ century China still did not compete for the hegemony on a global scale. Hence the United States could realise the environmental protection policy without any obstacles, which was natural due to being a highly developed country. It is connected with the expectations of its citizens in terms of clean environment. In the years 2000-2010 the percentage of patents on environmental technologies increased, which could have impact on the level of the emission of carbon dioxide (the Pearson correlation coefficient for the patents on environmental technologies and the level of the emission of pollutions in the years 2000-2016 amounts to -0.68).

The decreasing level of the emission of carbon dioxide in the United States can be also explained by the changing economic situation in some economic sectors. The level, share and dynamics of the emission of particular economic sectors in the years 2000-2014 are presented in table 3 .

Based on the data included in table 3 one can observe that each of the isolated sectors of economy has considerable participation in the emission of carbon 
dioxide, but in this aspect, there can be noticed advantage of the transport and industry sectors. The largest reduction of carbon dioxide in the years 2000-2017 took place in the industry sector (reduction by approx. 15.5\%) and it decided to a large degree on the success of the United States in the combat against global warming. Additionally, it needs emphasising that in the years 2000-2007 every economic sector, except for industry, recorded increases in the emission of carbon dioxide. It changed as late as after 2007.

TABLE 3

The emission of $\mathrm{CO}_{2}$ in particular economic sectors of the United States in the years 2000-2014

\begin{tabular}{|l|c|c|c|c|c|}
\hline \multirow{2}{*}{ Sector } & \multicolumn{3}{|c|}{$\begin{array}{c}\text { The emission of carbon } \\
\text { dioxide }\end{array}$} & \begin{tabular}{c} 
The sector's \\
participation in sector \\
in the total emission of \\
\cline { 2 - 6 } $\mathbf{C O}_{\mathbf{2}} \mathbf{( 2 0 1 4 )}$
\end{tabular} & $\begin{array}{c}\text { The dynamics } \\
\text { of the emission } \\
\text { of CO }\end{array}$ \\
$\mathbf{2 0 0 0}$ & $\mathbf{2 0 0 7}$ & $\mathbf{2 0 1 4}$ & $34 \%$ & $-2.94 \%$ \\
\hline Transport & 1870 & 2018 & 1815 & $2000)$ \\
\hline Industry & 1790 & 1667 & 1513 & $28 \%$ & $-15.47 \%$ \\
\hline Housing & 1185 & 1241 & 1115 & $21 \%$ & $-5.91 \%$ \\
\hline Commercial & 1022 & 1078 & 970 & $18 \%$ & $-5.09 \%$ \\
\hline
\end{tabular}

Source: own elaboration on the based: [www 9].

The analysis of the emission of carbon dioxide by the industry sector and of the real GDP generated by this sector in the years 2007-2014 indicated a relatively strong positive correlation between the analysed variables (the coefficient of the Pearson correlation coefficient for the analyzed variables amounts to 0.7). It means that the fluctuation of economic situation in the industry sector may have a relatively large importance for shaping the emission of carbon dioxide in industry. However, it needs to be added that the correlation between the analysed variables in the years 2003-2007 was also relatively strong (the Pearson correlation coefficient for the analysed variables amounts to -0.75 ) but it had negative value. It means that in the years 2003-2007 the increase of real GDP generated by the industry sector was usually connected with the reduction of the emitted carbon dioxide. The author assumes that such a relationship may result from the diversification of the dynamics of growth of specific branches of industry. For example, it is possible that in those years there occurred the offshoring of heavy industry (which is particularly responsible for the emission of carbon dioxide) simultaneously with the dynamic development of the industry based on high technologies which compensated with the surplus of GDP losses. However, such analysis goes far beyond the scope of this paper. 


\section{Conclusions}

The aim of the paper was to indicate the reason of too low determination of some countries in natural environmental protection. The increasing economic power of China (pretender) poses a real threat to the global domination of the United States (hegemon) and the international order they established. In such a situation those economic objectives that may be the source of advantage of one side, become more important than ecological objectives. There arises the situation known as the prisoner's dilemma. None of the sides is interested in conducting efficient environmental protection policy and since both sides considerably participate in the emission of carbon dioxide on the global scale, the protection of the global climate appears to be impossible or particularly difficult. Thus, the reason of too low determination of some countries in nature protection is the competition of these countries for hegemony.

According to the author and based on the conducted research it is necessary to confirm the following hypothesis: "State will not conduct efficient policy in terms of natural environmental protection in the conditions of its competition for hegemony". This hypothesis has been confirmed by certain facts. There is more noticeable rivalry among two world superpowers - China and the United States over the dominance in the global economy. While China as a developing country did not realise environmental protection policy to a large degree, there can be noticed the change of attitude as regards the United States. The country that so far has been actively protecting the environment while using administrative tools, begins to withdraw from it. Further environmental protection at such level would be very costly for the United States and certainly would not be helpful in the US - China rivalry for global hegemony title.

\section{References}

Bartkowiak R., 2013, Ekonomia rozpoju, Wydawnictwo PWE, Warszawa. Bartosiak J., 2016, Pacyfik i Eurazja. O wojnie, Wydawnictwo CSPA, Warszawa. Binmore K., 2017, Teoria gier, Wydawnictwo Uniwersytetu Lódzkiego, Łódź.

Dobrzańska B., Dobrzański G., Kiełczewski D., 2012, Ochrona środowiska prayyrodniczego, Wydawnictwo PWN, Warszawa.

Eberhardt P., 2012, Podstany teoretyczne $i$ ideowe geopolityki wedtug Rudolfa Kjelléna, „Przegląd geograficzny”, nr 84(2), s. 313-332, DOI: 10.7163/PrzG.2012.2.7.

Florczak W., 2011, Rozwój zrównoważony a dtugookresowy wzrost gospodarçy. Alternatywa çy koniunkcja? [w:] Teoretyczne aspekty ekonomii zrównoważonego rozwoju, Poskrobko B. (red.),Wydawnictwo Wyższej Szkoły Ekonomicznej w Białymstoku, Białystok. Heifetz A., 2012, Game Theory, Cambridge University Press, Cambridge.

Janik A., Lączny J., Ryszko A., 2009, Ekonomiczne podstany ochrony środowiska, Wydawnictwo Politechniki Śląskiej, Gliwice. 
Kleinowski M., 2010, Caynniki budujace site i potege państwa na arenie miedsynarodowej, „Świat Idei i Polityki”, t. 10, s. 9-36.

Kośmicki E., 2012, The Problems of Preservation and Sustainable Usage of Natural Heritage (the Analyses of the Basic Problems) [in:] Sustainable Development. Theory-Practice-Education, Pieńkowski D., Makarewicz-Marcinkiewicz A., Wiland-Szymańska J. (eds.), Wydawnictwo Ekonomia i Środowisko, Poznań - Białystok.

Malthus T., 1925, Prawo ludności, Druk W. Lanczyca i Spółki, Kraków.

Mankiw N., Taylor M., 2017, Microeconomics, Cengage Learning EMEA, Hampshire.

Prandecki K., 2016, Dobro wspólne a zrównoważony rožój, „Optimum. Studia Ekonomiczne”, nr 4(82), s. 55-68, DOI: 10.15290/ose.2016.04.82.05.

Rogall H., 2010, Ekonomia zrównoważonego rozwoju. Teoria i praktyka, Wydawnictwo Zysk i S-ka, Poznań.

Polityka gospodarcza, 2002, Winiarski B. (red.), Wydawnictwo PWN, Warszawa.

Żylicz T., 2014, Cena prąyrody, Wydawnictwo Ekonomia i Środowisko, Białystok.

www 1, https://www.tvn24.pl/wiadomosci-ze-swiata,2/greta-thunberg-ukradlisciemoje-marzenia-i-dziecinstwo-szczyt-klimatyczny-onz-w-nowym-jorku, $971888 . h t m l$ [date of entry: 24.10.2019].

www 2, http://biznesalert.pl/chiny-cop24/ [date of entry: 15.11.2019]. www 3, https://businessinsider.com.pl/wiadomosci/zmiana-klimatu-donald-trumpi-antyklimatyczna-polityka/049k2mf [date of entry: 15.11.2019].

www 4, https://www.forbes.pl/gospodarka/porozumienie-klimatyczne-usa-opuszczaporozumienie-z-paryza-4- listopada-2020-roku/6fsm3b3 [date of entry: 15.11.2019]. www 5, https://businessinsider.com.pl/wiadomosci/g20-o-zmianie-klimatu-usa-siewylamaly/m6r89jy [date of entry: 15.11.2019].

www 6, https://www.forbes.pl/gospodarka/porozumienie-klimatyczne-usa-opuszczaporozumienie-z-paryza-4-listopada-2020-roku/6fsm3b3 [date of entry: 15.11.2019]. www 7, https://businessinsider.com.pl/wiadomosci/g20-o-zmianie-klimatu-usa-sie-

wylamaly/m6r89jy [date of entry: 28.11.2019]. www 8, https://data.oecd.org/air/air-and-ghg-emissions.html [date of entry: 13.11.2019]. www 9, https://www.eia.gov/environment/emissions/carbon/ [date of entry: 26.11. 2019]. 